\title{
Antenatal and Post-natal Check-up Practices Among Chepang and Non-Chepang Communities of Nepal
}

\author{
Mayanath Ghimire $^{1} \&$ Prof. Dr. Ram Krishna Maharjan ${ }^{2}$ \\ ${ }^{1} \mathrm{PhD}$ Scholar, Mewar University, Rajasthan, India \\ Email: mayanathghimire@gmail.com \\ ${ }^{2}$ Professor of Tribhuvan University, Kathmandu, Nepal \\ Email: profmaharjan.rk@gmail.com
}

\begin{abstract}
Health check-up during pregnancy and after pregnancy is a must because of the critical health status of the mother and baby. The study identifies the health seeking behavior of mothers of Chepang and Non-Chepang communities of Makawanpur and Chitwan district of Nepal regarding the ANC and PNC check-up. The study was cross sectional descriptive design. Total sample size was 1250 (511 Non-Chepang and 739 Chepang). The result found that Non-Chepang community was found more aware and better practice of health check-up than Chepang communities in both districts. Nepal Government should focus on Chepang or similar types of marginalized and backward communities to increase their access on health services as well as concerned authorities should be responsible to address their problem which become as barrier to change their health seeking behavior.
\end{abstract}

KEYWORDS: Antenatal, Chepang, Check-up, Non-Chepang, Postnatal

\section{INTRODUCTION}

Antenatal, delivery and postnatal care services are amongst the recommended interventions aimed at preventing maternal and new-born deaths worldwide (Titaley, Hunter, Heywood, \& Dibley, 2010, p. 1). It is accepted that all women should seek antenatal care early in pregnancy. Many do, but there are still some women who do not present for care until very late in the pregnancy or even in labour itself (RaniSandhya, Ghosh, \& Sharan, 2007, p. 57). Women from culturally marginal groups who did not have the educational opportunities encourage preventive health care, who do not have adequate access to health care services because of lack of transport and the distance they live from the health care facility, with few financial resources to meet the expectations or requirements of the health care services or providers for payment, with restrictive home situations where other members of the family prohibit attendance at health care services, to name only a few reasons, are less likely to seek appropriate and timely care (WHO Regional Office for Europe, 2002, p. 24).

It highlights the care of antenatal mothers as an important element in maternal health care as appropriate care which will lead to successful pregnancy outcome and healthy babies. All pregnant ladies are recommended to go for their first antenatal check-up in the first trimester to 
identify and manage any medical complication as well as to screen them for any risk factors that may affect the progress and outcome of their pregnancy (Rosliza \& Muhamad, 2011, p. 13).

Postnatal care (PNC) is the most neglected area in the health care delivery system despite being very important time for the provision of interventions that are vital to the health of both the mother and the new born infant. Consequently, serious complications which account for two thirds of all maternal and neonatal deaths occur during the postnatal period (Chimtembo, Maluwa, Chimwaza, Chirwa, \& Pindani, 2013, p. 343).

The general purpose of this study was to identify the antenatal and post-natal check-up practices among Chepang and Non-Chepang communities of Makawanpur and Chitwan districts of Nepal.

\section{METHODOLOGY}

The study is based on descriptive study. The study was based on descriptive and cross sectional design. It was carried out in Chitwan and Makawanpur from Sep. - Oct, 2014 among the 1250 respondents. Respondents were selected from mothers having 3-5 years children from those districts. Ethical approval was taken from Nepal Health Research Council for data collection and written consent was taken from each respondent. Census method was applied to select the household of Chepang communities and random sampling was done for Non-Chepang communities in both districts. Mothers were the key respondents of this study. Primary data were collected by using the structured questionnaires. Simple frequency distribution is done to identify the health seeking behavior of mothers. Comparative study was done between the Chepang and Non-Chepang communities.

\section{RESULTS}

In total, data show that $40.9 \%$ Non-Chepang mothers was selected from Makawanpur and Chitwan districts whereas $59.1 \%$ mothers was from Chepang. On the basis of district, in total $53 \%$ respondents was participated from Chitwan followed by $47 \%$ from Makawanpur district.

\section{Hospital check-up practices}

During the study, information was collected about the health seeking behaviour of mother during the time of pregnancy. Regular health check up is important because pregnancy period is understood as the critical period also.

Table no. 1 shows that in total $91.5 \%$ reported to have visited hospital for health checkup during the pregnancy period. Among the data, $42.78 \%$ was Non-Chepang and $57.22 \%$ was Chepang. Within the ethnicity, out of 511 Non-Chepang, 489 (95.69\%) and out of 739 Chepang, $654(88.49 \%)$ said that they had visited hospital for health check-up. The data presents that health seeking behaviour was found good among the Non-Chepang communities as compared to Chepang communities. 
Table 1: Hospital check up

\begin{tabular}{|c|c|c|c|c|c|c|c|c|c|c|}
\hline \multirow[b]{2}{*}{ Category } & \multicolumn{3}{|c|}{ Makawanpur } & \multicolumn{3}{|c|}{ Chitwan } & \multicolumn{4}{|c|}{ Grand Total } \\
\hline & \begin{tabular}{|c|} 
Non- \\
Chepang
\end{tabular} & Chepang & Total & $\begin{array}{c}\text { Non- } \\
\text { Chepang }\end{array}$ & Chepang & Total & \begin{tabular}{c|} 
Non- \\
Chepang
\end{tabular} & Chepang & Total & $\%$ \\
\hline Checked & 292 & 261 & 553 & 197 & 393 & 590 & 489 & 654 & 1143 & 91.5 \\
\hline $\begin{array}{l}\text { Not } \\
\text { Checked }\end{array}$ & 9 & 8 & 17 & 1 & 71 & 72 & 10 & 79 & 89 & 7.1 \\
\hline $\begin{array}{l}\text { Not } \\
\text { Stated }\end{array}$ & 12 & 6 & 18 & - & - & - & 12 & 6 & 18 & 1.4 \\
\hline Total & 313 & 275 & 588 & 198 & 464 & 662 & 511 & 739 & 1250 & 100 \\
\hline$\%$ & 53.2 & 46.8 & 47 & 30 & 70 & 53 & 40.9 & 59.1 & 100 & \\
\hline
\end{tabular}

District wise, data shows that out of 313 Non-chepang, 292 (93.29\%) followed by out of

275 Chepang, 261 (94.90\%) visited health post for health check-up in Makawanpur district. Similarly, out of 198 Non-chepang, 197 (99.49\%) followed by out of 464 Chepang, 393 $(84.69 \%)$ visited health post for health check-up in Chitwan district. As shown in the data, higher number of Non-Chepang of Chitwan as compare to Makawanpur district was found more aware on visiting the health post. Whereas, Chepangs were found more aware in Makawanpur district as compare to Chitwan.

\section{Checking times}

As the medical rules set in Nepal, minimum 4 ANC check-up is mandatory for the safe delivery. So respondents were asked about their practices of visiting the health post for ANC check-up. Table no. 2 shows that out of total 1143 respondents, $63.5 \%$ had visited less than 4 times followed by only $36.5 \%$ who had visited four and more than four times during the pregnancy period for ANC check-up. Ethnicity wise, $42.1 \%$ Non-Chepang followed by $79.5 \%$ Chepang had visited less than 4 times. Whereas, $57.9 \%$ Non-Chepang followed by only $20.5 \%$ Chepang had visited four and more than four times for ANC check-up.

Table 2: Checking times

\begin{tabular}{|c|c|c|c|c|c|}
\hline District & \multicolumn{2}{|c|}{ Ethnicity } & $<$ four times & $\geq$ four times & Total \\
\hline \multirow{6}{*}{ Makawanpur } & \multirow{2}{*}{ Non-Chepang } & \# & 153 & 139 & 292 \\
\hline & & $\%$ & 52.4 & 47.6 & 100 \\
\hline & \multirow{2}{*}{ Chepang } & \# & 256 & 5 & 261 \\
\hline & & $\%$ & 98.1 & 1.9 & 100 \\
\hline & \multirow{2}{*}{ Total } & \# & 409 & 144 & 553 \\
\hline & & $\%$ & 74.0 & 26.0 & 100 \\
\hline \multirow{6}{*}{ Chitwan } & \multirow{2}{*}{ Non-Chepang } & \# & 53 & 144 & 197 \\
\hline & & $\%$ & 26.9 & 73.1 & 100 \\
\hline & \multirow{2}{*}{ Chepang } & $\#$ & 264 & 129 & 393 \\
\hline & & $\%$ & 67.2 & 32.8 & 100 \\
\hline & \multirow{2}{*}{ Total } & \# & 317 & 273 & 590 \\
\hline & & $\%$ & 53.7 & 46.3 & 100 \\
\hline \multirow{3}{*}{ Total } & \multirow{2}{*}{ Non-Chepang } & \# & 206 & 283 & 489 \\
\hline & & $\%$ & 42.1 & 57.9 & 100 \\
\hline & Chepang & \# & 520 & 134 & 654 \\
\hline
\end{tabular}




\begin{tabular}{|l|l|l|l|l|} 
& $\%$ & 79.5 & 20.5 & 100 \\
\hline \multirow{2}{*}{ Total } & $\#$ & 726 & 417 & 1143 \\
\cline { 2 - 5 } & $\%$ & 63.5 & 36.5 & 100 \\
\hline
\end{tabular}

District wise, out of 292 Non-Chepang, 52.4\% visited less than four times and $47.6 \%$ visited four and more than four times whereas out of 261 Chepang, 98.1\% visited less than four times and only $1.9 \%$ visited four and more than four times for ANC check-up in Makawanpur district. Similarly, $26.9 \%$ Non-Chepang followed by $67.2 \%$ Chepang visited less than four times whereas $73.1 \%$ Non-Chepang followed by $32.8 \%$ Chepang visited at least four or more than four times for ANC check-up in Chitwan district. The data shows that in both districts, frequency of ANC visit is low among the Chepang communities than the Non-Chepang communities. In general, situation of Chitwan district is better than Makawanpur district.

\section{Use of Iron tablet during pregnancy}

Medical doctors recommend Iron tablets for pregnant women to maintain the level of Iron in body.

The data shows that in total, $82.9 \%$ had taken Iron tablet during the pregnancy period. Out of 511 Non-Chepang, 91\% and out of 739 Chepang, $77.3 \%$ had taken Iron tablet. The data shows that, comparatively, Chepang had done less health seeking practices in comparison of Non-Chepang communities.

Table 3: Use of Iron tablet during pregnancy

\begin{tabular}{|c|c|c|c|c|c|c|}
\hline District & \multicolumn{2}{|c|}{ Ethnicity } & \multirow{2}{*}{$\begin{array}{c}\text { Yes } \\
268\end{array}$} & \multirow{2}{*}{$\begin{array}{l}\text { No } \\
9\end{array}$} & Not Stated & \multirow{2}{*}{$\begin{array}{l}\text { Total } \\
313\end{array}$} \\
\hline \multirow{6}{*}{ Makawanpur } & \multirow{2}{*}{ Non-Chepang } & \# & & & 36 & \\
\hline & & $\%$ & 85.6 & 2.9 & 11.5 & 100 \\
\hline & & $\#$ & 143 & 12 & 120 & 275 \\
\hline & Chepang & $\%$ & 52.0 & 4.4 & 43.6 & 100 \\
\hline & Totol & $\#$ & 411 & 21 & 156 & 588 \\
\hline & I otal & $\%$ & 69.9 & 3.6 & 26.5 & 100 \\
\hline \multirow{6}{*}{ Chitwan } & \multirow{2}{*}{ Non-Chepang } & $\#$ & 197 & 1 & - & 198 \\
\hline & & $\%$ & 99.5 & 0.5 & - & 100 \\
\hline & \multirow{2}{*}{ Chepang } & $\#$ & 428 & 35 & 1 & 464 \\
\hline & & $\%$ & 92.2 & 7.5 & 0.2 & 100 \\
\hline & \multirow{2}{*}{ Total } & $\#$ & 625 & 36 & 1 & 662 \\
\hline & & $\%$ & 94.4 & 5.4 & 0.2 & 100 \\
\hline \multirow{6}{*}{ Total } & \multirow{2}{*}{ Non-Chepang } & $\#$ & 465 & 10 & 36 & 511 \\
\hline & & $\%$ & 91.0 & 2.0 & 7.0 & 100 \\
\hline & \multirow{2}{*}{ Chepang } & $\#$ & 571 & 47 & 121 & 739 \\
\hline & & $\%$ & 77.3 & 6.4 & 16.4 & 100 \\
\hline & \multirow{2}{*}{ Total } & \# & 1036 & 57 & 157 & 1250 \\
\hline & & $\%$ & 82.9 & 4.6 & 12.6 & 100 \\
\hline
\end{tabular}

District wise, $85.6 \%$ Non-Chepang followed by 52\% Chepang had taken Iron table in Makawanpur district whereas 99.5\% Non-Chepang followed by $92.2 \%$ Chepang had taken Iron tablet in Chitwan district. Health seeking practices were found better in Chitwan district in both communities than the Makawanpur district.

\section{Birthing Centre}


Nepal Government has promoted the institutional based delivery through the governmental and non-governmental agencies. Birthing place is one of the important factors to determine the risk of live and death of mother and baby.

The data of table no. 4 shows that $55.9 \%$ had given birth of last baby in home followed by $12.7 \%$ in health post, $26.8 \%$ in hospital and $4.6 \%$ had not stated. In total, home-based delivery is high. Ethnicity wise, $26.2 \%$ Non-Chepang as compared to $76.5 \%$ Chepang who had given birth of last baby in home. Only $11.4 \%$ and $7.6 \%$ Chepang had visited health post and hospital respectively for delivery whereas $14.7 \%$ and $54.6 \%$ Non-Chepang had visited health post and hospital respectively for delivery. The practice of home based delivery is found high among the Chepang communities which creates the high risk in mortality of mother and baby.

Table 4: Birthing Place

\begin{tabular}{|c|c|c|c|c|c|c|c|}
\hline District & Ethnici & & Home & Health Post & Hospital & Not Stated & Total \\
\hline \multirow{6}{*}{ Makawanpur } & \multirow{2}{*}{ Non-Chepang } & $\#$ & 104 & 73 & 113 & 23 & 313 \\
\hline & & $\%$ & 33.2 & 23.3 & 36.1 & 7.3 & 100 \\
\hline & \multirow{2}{*}{ Chepang } & $\#$ & 118 & 77 & 47 & 33 & 275 \\
\hline & & $\%$ & 42.9 & 28.0 & 17.1 & 12.0 & 100 \\
\hline & \multirow{2}{*}{ Total } & $\#$ & 222 & 150 & 160 & 56 & 588 \\
\hline & & $\%$ & 37.8 & 25.5 & 27.2 & 9.5 & 100 \\
\hline \multirow{6}{*}{ Chitwan } & \multirow{2}{*}{ Non-Chepang } & $\# \mathrm{t}$ & 30 & 2 & 166 & - & 198 \\
\hline & & $\%$ & 15.2 & 1.0 & 83.8 & - & 100 \\
\hline & \multirow{2}{*}{ Chepang } & $\#$ & 447 & 7 & 9 & 1 & 464 \\
\hline & & $\%$ & 96.3 & 1.5 & 1.9 & 0.2 & 100 \\
\hline & \multirow{2}{*}{ Total } & $\#$ & 477 & 9 & 175 & 1 & 662 \\
\hline & & $\%$ & 72.1 & 1.4 & 26.4 & 0.2 & 100 \\
\hline \multirow{6}{*}{ Total } & \multirow{2}{*}{ Non-Chepang } & $\#$ & 134 & 75 & 279 & 23 & 511 \\
\hline & & $\%$ & 26.2 & 14.7 & 54.6 & 4.5 & 100 \\
\hline & \multirow{2}{*}{ Chepang } & \# & 565 & 84 & 56 & 34 & 739 \\
\hline & & $\%$ & 76.5 & 11.4 & 7.6 & 4.6 & 100 \\
\hline & \multirow{2}{*}{ Total } & $\#$ & 699 & 159 & 335 & 57 & 1250 \\
\hline & & $\%$ & 55.9 & 12.7 & 26.8 & 4.6 & 100 \\
\hline
\end{tabular}

District wise, $33.2 \%$ Non-Chepang followed by $42.9 \%$ Chepang had delivered in home and only $36.1 \%$ Non-Chepang, $17.1 \%$ Chepang visited hospital for safe delivery in Makawanpur district. Similarly, $15.2 \%$ Non-Chepang followed by $96.3 \%$ Chepang gave birth to baby in home and $83.8 \%$ Non-Chepang followed by only $1.9 \%$ Chepang visited hospital for safe delivery in Chitwan. From the analysis of data, it is found that institutional based delivery practices is very low among the Chepang in general in both the districts. District wise, Non-Chepang of Chitwan were found more aware about the safe delivery that had better practice to visit the hospital for delivery than the Makawanpur district whereas Chepangs of Makawanpur district were found more conscious to visit the hospital for delivery than the Chitwan district. So, it can be said that location is not important to determine the institutional based delivery practices.

\section{Post Delivery Checking Status}

In general, respondents were asked about their practices to visit the health post or hospital for post-delivery health check-up. The data presents that in total, 69.4\% had done post-delivery health check-up whereas yet more than $30 \%$ mothers had not visited health post for their post- 
JOURNAL OF ADVANCED ACADEMIC RESEARCH (JAAR)

July 2014

delivery check-up. In total, $89.6 \%$ Non-Chepang followed by $55.3 \%$ had reported that they had visited health post for post-delivery check-up. The findings inform that still around $45 \%$ Chepang are not aware about the importance of post-delivery health check-up.

Table 5: Post Delivery Checking Status

\begin{tabular}{|c|c|c|c|c|c|c|}
\hline District & & city & Yes & No & Not Stated & Total \\
\hline \multirow{6}{*}{ Makawanpur } & \multirow{2}{*}{ Non-Chepang } & \# & 266 & 46 & 1 & 313 \\
\hline & & $\%$ & 85.0 & 14.7 & 0.3 & 100 \\
\hline & \multirow{2}{*}{ Chepang } & \# & 229 & 45 & 1 & 275 \\
\hline & & $\%$ & 83.3 & 16.4 & 0.4 & 100 \\
\hline & \multirow{2}{*}{ Total } & \# & 495 & 91 & 2 & 588 \\
\hline & & $\%$ & 84.2 & 15.5 & 0.3 & 100 \\
\hline \multirow{6}{*}{ Chitwan } & \multirow{2}{*}{ Non-Chepang } & $\#$ & 192 & 6 & - & 198 \\
\hline & & $\%$ & 97.0 & 3.0 & - & 100 \\
\hline & \multirow{2}{*}{ Chepang } & \# & 180 & 284 & - & 464 \\
\hline & & $\%$ & 38.8 & 61.2 & - & 100 \\
\hline & \multirow{2}{*}{ Total } & \# & 372 & 290 & - & 662 \\
\hline & & $\%$ & 56.2 & 43.8 & - & 100 \\
\hline \multirow{6}{*}{ Total } & \multirow{2}{*}{ Non-Chepang } & \# & 458 & 52 & 1 & 511 \\
\hline & & $\%$ & 89.6 & 10.2 & 0.2 & 100 \\
\hline & \multirow{2}{*}{ Chepang } & \# & 409 & 329 & 1 & 739 \\
\hline & & $\%$ & 55.3 & 44.5 & 0.1 & 100 \\
\hline & \multirow{2}{*}{ Total } & \# & 867 & 381 & 2 & 1250 \\
\hline & & $\%$ & 69.4 & 30.5 & 0.2 & 100 \\
\hline
\end{tabular}

District wise data shows that $84.2 \%$ followed $56.2 \%$ had done post-delivery check-up in Makawanpur and Chitwan district respectively. Among the ethnicity, 85\% Non-Chepang followed by $83.3 \%$ Chepang in Makawanpur district and 97\% Non-Chepang followed by $38.8 \%$ Chepang in Chitwan district had visited health post for post-delivery check-up. Data presents that in total, post-delivery health check-up practices was found better in Makawanpur district than Chitwan. Similarly, more than $80 \%$ Chepang and Non-Chepang had practiced post-delivery check-up in Makawanpur whereas very low number of people reported post-delivery check-up practices among the Chepang in comparison of Non-Chepang in Chitwan district. So, mothers of Chepang need orientation about the importance of post-delivery health check-up in Chitwan district.

\section{ANC and PNC Checking Place}

Awareness and access are the two major determinants of checking place for ANC or PNC. Table no. 6 shows that $26.1 \%$ respondent visited health post followed by $46.9 \%$ visited hospital for check-up. Among them, 21.2\% Non-Chepang followed by 31.5\% Chepang visited health post and $60.9 \%$ Non-Chepang followed by $31.3 \%$ Chepang visited hospital for health related treatment.

Table 6: ANC and PNC Checking Place

\begin{tabular}{|c|l|l|l|l|l|l|}
\hline District & \multicolumn{2}{|c|}{ Ethnicity } & Health Post & Hospital & Not Stated & \multicolumn{1}{c|}{ Total } \\
\hline \multirow{3}{*}{ Makawanpur } & \multirow{2}{*}{ Non-Chepang } & $\#$ & 81 & 125 & 60 & 266 \\
\cline { 2 - 7 } & & $\%$ & 30.5 & 47.0 & 22.6 & 100 \\
\cline { 2 - 7 } & Chepang & $\#$ & 64 & 122 & 43 & 229 \\
\hline
\end{tabular}




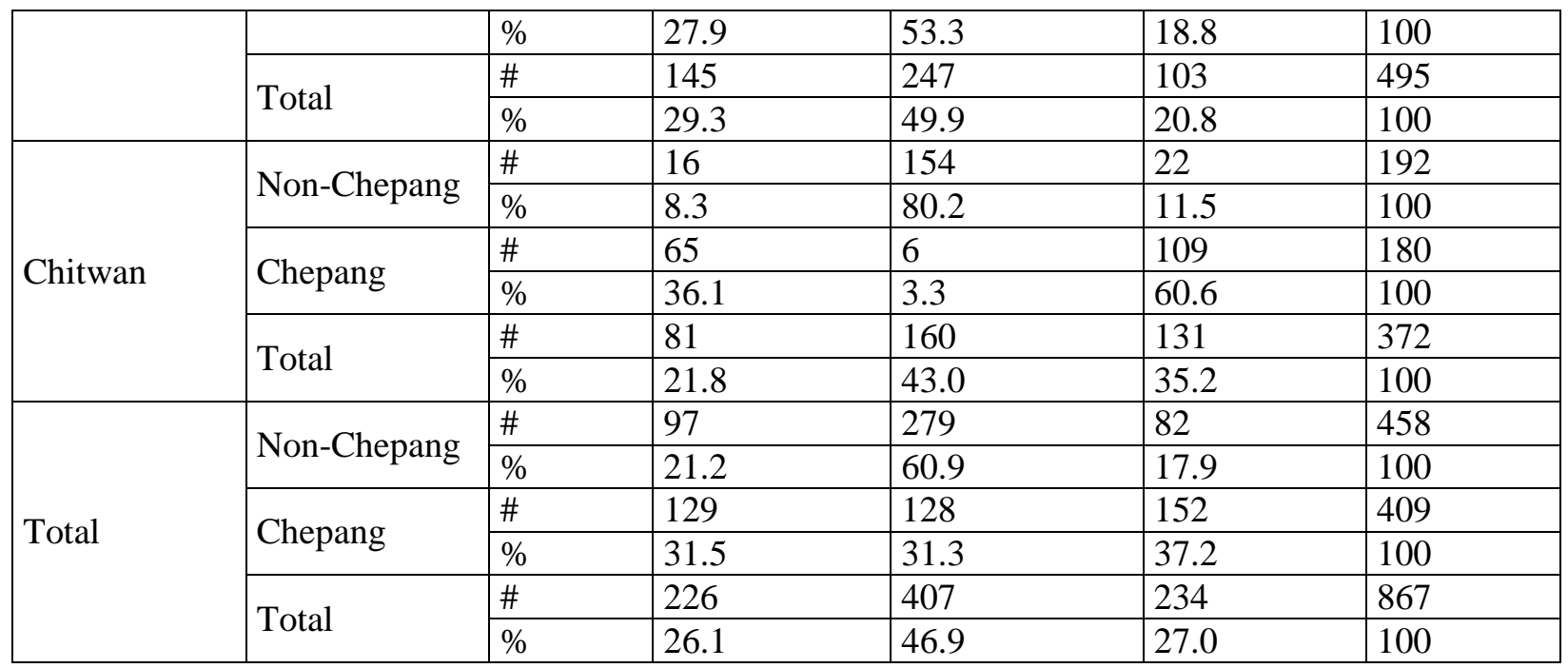

The above table shows that $29.3 \%$ followed by $49.9 \%$ visited health post and hospital respectively for health check-up in Makawanpur district. Similarly, 21.8\% followed by $43 \%$ visited health post and hospital respectively for health check-up in Chitwan district. There was a significant difference found between the two districts regarding the visiting health post and hospital for check-up. Similarly, within the district, 30.5\% Non-Chepang followed by $27.9 \%$ Chepang visited health post and $47 \%$ Non-Chepang followed by $53.3 \%$ Chepang visited hospital in Makawanpur district and 8.3\% Non-Chepang followed by 36.1\% Chepang visited health post and $80.2 \%$ Non-Chepang followed by 3.3\% Chepang visited hospital in Chitwan district. In Chitwan, more than $60 \%$ Chepang did not state their checking places.

\section{DISCUSSIONS}

The study has focused on the six different issues: hospital check-up, checking times, use of Iron tablet during pregnancy, birthing place, post-delivery check up and ANC and PNC checking place to explore the health seeking behavior of mother during the ANC and PNC periods. The study identified that in total $91.5 \%$ reported that they had visited hospital for health check-up during the pregnancy period. The UNICEF report shows that in total $19 \%$ children birth is done with the help of skilled birth attendant (KBA). 54\% under five-year' children died within the one year. 5\% children are suffering from malnutrition and $13 \%$ are severe malnutrition in Nepal. (UNICEF, 2011, pp. 14-17).

It is well accepted issue that pregnancy period is the critical period for women so they need close care of family and regular check-up from medical person. The study has found that in total, 63.5\% had visited at least1 time during the pregnancy period for ANC check-up. Comparatively some better result was found by Nepal Health Sector Program in ANC visit. Pregnant female receiving Antenatal Care (ANC) - 77\% women had received at least one ANC check-up and $57 \%$ having has visit first ANC visit fist four month pregnancy. Total $86 \%$ get receiving care ANC from government institution and other from non-governmental provider. (HHSP II, 2012, p. 169).

The study has also discussed on the issue of the use of Iron tablet during pregnancy period. The data shows that in total, $82.9 \%$ had taken Iron tablet during the pregnancy period. As 
the study conducted on fooding practices during the pregnancy by Save the Children found that the women are rely heavily on staples and legumes and eat animal source foods only infrequently with less than 20 per cent of women consume green leafy vegetables and less than 20 per cent consume vitamin A rich fruits and vegetables. Less than one-third of women report an increase in food consumption during pregnancy (SUAAHARA, 2013, pp. 8-9).

As the health policy of Nepal government that government has promoted the institutional based delivery. Ama program is designed to promote the institutional based delivery. It provides free delivery care in referred hospital. The study found that still $55.9 \%$ had given birth of last baby in home. Only $11.4 \%$ and $7.6 \%$ Chepang had visited health post and hospital respectively for delivery whereas $14.7 \%$ and $54.6 \%$ Non-Chepang had visited health post and hospital respectively for delivery in Chitwan and Makawanpur districts. The situation of institutional based delivery is critical in study areas. The report of Nepal Health Sector Program shows the more critical result than the present study in place of delivery. Place of delivery- $61 \%$ delivered in their home and 35\% delivered in their counterparts. Among them $26 \%$ delivered in government facility, 16\% was in government hospital. (Nepal Health Sector Program, 2012, p. 169). According to the house hold survey report of Ama programme (including 4ANC)- over two-thirds $(69 \%)$ of the mother used government hospital taken free delivery care, 55\% taken primary health care (PHCCs) (Nepal Health Sector Program, 2012, pp. i-xiv).

As the importance of ANC check-up, PNC check-up is also equally importance to insure the health status of mother and baby. The data of present study found that in total, $69.4 \%$ had done post-delivery health check-up. As the finding discussed with the previous study found that Postnatal Care (PNC)- PNC received after delivery was 75\% women delivered in a facility received at least one postnatal check-up, 13\% had had at least three postnatal check-ups (Nepal Health Sector Program, 2012, p. 190).Infant check-ups: 78\% of infants were check-up before discharge. There were no significant differences by urban/rural residence, ecological zone, educational level or caste/ethnicity (Nepal Health Sector Program, 2012, p. 208). According to the report of Save the Children, mental, new-born and child health program scale up use of household to hospital continuum of maternal and new-born case as $73 \%$ of women (64\% was in 2 012) used skilled birth attendants for delivery andon an average $72 \%$ (target was \%) received the recommended three visit in seven day after delivery for new born care in Bajura, Baitadi and Udayapur (SUAAHARA, 2013).

The present study found that $26.1 \%$ respondents visited health post followed by $46.9 \%$ visited hospital for ANC and PNC check-up in Makawanpur and Chitwan district of Nepal. As the finding discussed with the report of Nepal Health Sector Program found that place of the care (outpatients)- seeing outpatients care $60 \%$ had utilized non-government facilities and $40 \%$ had used a government facility. Most had attended a private hospital/clinic 47\%, governmental hospital attended 12\%, Health Post (HPs) 13\% and Sub-Health Post (SHPs) service took 11\% (Nepal Health Sector Program, 2012, p. 240).

\section{CONCLUSIONS}


The article discussed on the practices of mothers' health seeking behaviours of Chepang and Non-Chepang communities of Makawanpur and Chitwan districts from descriptive analysis. Chepang of Makawanpur district were found more aware in health check-up practices than Chepang of Chitwan district. In general, situation of Chitwan district is better than Makawanpur district regarding the ANC check-up. Institutional based delivery practices was found better among Non-Chepang communities than Chepang communities in both districts. So, the minorities and backward communities need the intensive awareness program to change their health seeking behaviour. Awareness, education and poverty are the major factors to increase the frequency of health check-up. The study had not explored the causative factors of not practicing the institutional based delivery from in-depth study so further research is necessary to identify these causative factors and better way to promote the health program.

\section{BIBLIOGRAPHY}

Save the children. (2013). Summary SUAAHARA Baseline Survey Report. Save the children.

Kathmandu: International Food Policy Research Institute (IFPRI).

Biswas, S., Bose, K., \& Mukhopadhyay, A. (2010). Mid-upper Arm Circumference Based Undernutrition among Bengalee Children of Chapra, West Bengal, Indis. Iran J Pediatr, 20(1), 63-68.

Chimtembo, L. K., Maluwa, A., Chimwaza, A., Chirwa, E., \& Pindani, M. (2013, August). Assessment of quality of postnatal care services offered to mothers in Dedza district, Malawi. Open Journal of Nursing, 3, 343-350. doi:10.4236/ojn.2013.34046

Government of Nepal Ministry of Health and Population Department of Health. (2011). Annual Report. Department of Health Services. Kathmadu: Department of Health Services. Retrieved Feb 2011

Nepal Health Sector Program. (2012). Nepal House Hold Survey. Ministry of Health and Population. Kathmandu: Government of Nepal.

Park, K. (2007). Preventive and Social Medicine (19 ed.). Jabalpur: Prem Nagar, Baharsides Bhanot 1167, Prem Nagar Jabalpur, India. Retrieved Feb 2007

RaniSandhya, Ghosh, S., \& Sharan, M. (2007, December 1-7). Maternal Healthcare Seeking among Tribal Adolescent Girls in Jharkhand. Economic and Political Weekly, 42(48), 5661. Retrieved from http://www.jstor.org/stable/40276718

Rosliza, A., \& Muhamad, J. (2011). KNOWLEDGE, ATTITUDE AND PRACTICE ON ANTENATAL CARE AMONG ORANG ASLI WOMEN IN JEMPOL, NEGERI SEMBILAN. Malaysian Journal of Public Health Medicine, 11(2), 13-21. Retrieved from

http://www.indigenouspeoplesissues.com/attachments/article/13966/KNOWLEDGEATTITUDE-PRACTICE-ANTENATAL-CARE.pdf

Sethuraman, K., \& Duvvury, N. (2007). The Nexus of Gender Discrimination with Malnutrition: An Introduction. Economic and Political Weekly, 42(44), 51-53. 
Titaley, C. R., Hunter, C. L., Heywood, P., \& Dibley, M. J. (2010). Why don't some women attend antenatal and postnatal care services?: a qualitative study of community members' perspectives in Garut, Sukabumi and Ciamis districts of West Java Province, Indonesia. BMC Pregnancy and Childbirth, 10(61), 1-12. Retrieved from http://www.biomedcentral.com/content/pdf/1471-2393-10-61.pdf

UNICEF. (2011). IN Nepal UNICEF. Kathmandu: Jagadamba Press Pvt.

Uyanga, J. (1981). The Regional Correlates of Child Nutrition in Rural Southeastern Nigeria. Geo Journal, 5(4), 331-337.

WHO Regional Office for Europe. (2002). Essential Antenatal, Perinatal and Postpartum Care. Promoting Effective Perinatal Care. Retrieved from http://www.euro.who.int/_data/assets/pdf_file/0013/131521/E79235.pdf

Yang, C., Sangthong, R., Chongsuvivatwong, V., McNeil, E., \& Lu, L. (1979). Effect of village income and household income on sanitation facilities, hygiene behavioursand child undernutrition during rapid economic growth in a rural cross-border area, Yunnan,China. Journal of Epidemiology and Community Health, 63(5), 403-407. 